\title{
Volatility Exchange Rate and Economic Growth: Insight from ASEAN Member Countries
}

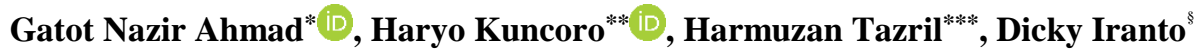

\begin{abstract}
This study aims to determine the effect of exchange rate volatility on economic growth in the ASEAN member countries (Indonesia, Thailand, Vietnam, and Cambodia) through investment. Based on the previous studies, the researcher focuses on developing the initial research analysis because it can control different company levels' characteristics and then determine the impact of exchange rate changes on economic growth mediated by investment. There is a limited analysis of whether exchange rate movements encourage overall investment in this study's particular direction. The author's primary focus is whether the export or import channels or both play an essential role in determining a company's investment. This study's population is in ASEAN member countries that have been published by the World Bank (https://www.worldbank.org/) and continue to exist during the period 1998-2019. The sample selection in this study used a purposive sampling method. Some of the ratio data were available in the financial report summary. The analysis method used in the study is the path analysis.
\end{abstract}

Keywords: economics growth; export-investment; import-investment; volatility exchange rate.

JEL classification: F10; F13; F14.

\section{INTRODUCTION}

In developing countries, carrying out national development requires a large number of funds. This situation happens because there are efforts from these countries to catch up with the development gap compared to developed countries (Primi \& Toselli, 2020). The economy of the Southeast Asian region still depends a lot on natural products, except for Singapore.

\footnotetext{
Faculty of Economics Universitas Negeri Jakarta, Komplek IKIP Rawamangun Muka Indonesia; e-mail: ahmad72nazir@gmail.com (corresponding author).

Faculty of Economics Universitas Negeri Jakarta, Komplek IKIP Rawamangun Muka Indonesia; e-mail: har_kun@feunj.ac.id.

Faculty of Economics Universitas Negeri Jakarta, Komplek IKIP Rawamangun Muka Indonesia; e-mail: harmuzan@gmail.com.

$\S$ Faculty of Economics Universitas Negeri Jakarta, Komplek IKIP Rawamangun Muka Indonesia; e-mail: dicky@unj.ac.id.
} 
The establishment of the Southeast Asia free trade area by ASEAN countries is expected to accelerate this region's economic growth (Ishikawa, 2021).

With limited supplies in a country, import activities were initiated. Export-import activities can also foster harmonious relations between nations. Through this international trade, many parties are mutually beneficial, both from selling profits and profits from fulfilling needs. Export and import are also some of the most influential jobs for business people. Every country has natural wealth or natural resources that are different from one another. Therefore, a commodity that is not available between one country and another is needed. With these commodities, there will be trade or exchange of things between one country and another. There were export and import activities for each country. Exporters and producer exporters carry out international trade, export, and import to sell and purchase a commodity with foreigners, foreign nations, and foreign countries. The sellers and buyers, commonly referred to as exporters and importers, make payments in foreign currency (Oglend \& Straume, 2020).

The impact of exchange rate volatility is also an indication of economic activity changes, especially in foreign trade, which has been widely discussed in the literature considering its significant role in international trade (Vaio, Palladino, Hassan, \& Escobar, 2020). However, to date, there has been no consensus on the effects of nominal and real exchange rate movements on economic activity, although a large amount of literature investigates how exchange rates might affect firms or industries' performance.

Despite attempts to identify the relationship between exchange rates and investment, there is almost no consensus in the literature on whether currency appreciation causes investment to increase or decrease. The existing literature examines this relationship using firm-level data (Andries \& Hunermund, 2020). However, it is difficult to explain the differences at the macro level. In other words, although this study can justify the investment response of an individual firm, there is limited analysis on whether movements in exchange rates are driving overall investment in a particular direction. Given the limitations of this existing research, this section reviews some of the empirical literature closely related to the purpose of this article. For example, Permani (2021) and Swift (2006) examines the relationship between exchange rate appreciation and investment and use Australian manufacturing firms to document that investment is negatively related to the share of exports in total sales and positively related to the allocation of imports. The increase in investment, driven by the percentage of imports, was most pronounced in the equipment and manufacturing and machinery sectors, which tend to rely on imported intermediate goods for production (Civcir, Panshak, \& Ozdeser, 2021). This condition applies to Japan. Thus, Hotei (2012) suggests that the Japanese yen's appreciation will lead to a decrease in investment for some industries while investment in oil and coal products increases. Nucci and Pozzolo (2001) and Rapetti (2020) also note that there are cost and revenue channels that can work in different directions in response to exchange rate movements. They separated these channels according to data availability and found similar results. Similarly, Michail (2021) and Mlambo (2020) find that exchange rate appreciation increases investment due to the importance of imported goods in the manufacturing sector.

To explore these objectives, the researcher focuses on the relationship between exchange rate fluctuations and investment by looking at the micro-level census of data on firms. The data provides detailed information about a company's balance sheet and ownership. Given the data availability, the authors consider two possible channels, namely exports (income) and imports (costs), in determining the determinants of firm investment decisions. Based on the 
existing literature, this article examines the investment behaviour of companies. It determines the extent and direction of exchange rate appreciation to encourage aggregate investment in the ASEAN Member States.

\section{LITERATURE REVIEW}

Investment is the expenditure and expenditure of investment or companies to buy capital goods and equipment to increase the ability to produce goods and services available in the economy. According to Andren and Jankensgard (2020), the definition of investment is an activity carried out by utilizing cash in the present, intending to produce goods in the future. According to Ahiakpor (2020), it is an activity related to the effort to draw resources used to procure capital goods at this time. These capital goods will generate new product flows in the future. Bhattacharya, Good, and Sardashti (2020) also revealed that investment is an activity related to drawing resources to be used to procure goods.

The role of exchange rates in the formation of corporate capital has been a somewhat less explored factor. From the traditional trade channel perspective, exchange rate depreciation is expected to have an expansionary effect on investment activity. The classic Mundell-Fleming model shows that the depreciation of the exchange rate will increase the competitiveness of exports and, hence, production, leading to an increase in firm investment (Rapetti, 2020). A more direct and immediate effect works through export earnings. The depreciation of the exchange rate will immediately increase export earnings and hence the company's cash flow, which will expand the company's investment capacity (Dao, Minoiu, \& Ostry, 2017). There is also a strand of literature that shows that the exchange rate does not significantly influence investment. Alaali (2020) and Beckmann, Czudaj, and Arora (2020) investigated manufacturing firms and concluded that it is difficult to find a significant relationship between exchange rates and investment. Caglayan and Torres (2011) and Edo Edo, Osadolor, and Dading (2020) show, in contrast to the conclusion of the previous article, that the decline in the domestic currency value has a positive impact on investment through the export channel.

There are three approaches to investment theory: the classical approach, the neoclassical approach, and the Keynesian approach. The Keynesian approach divides it into two: Marginal Efficiency of Capital (MEC) or internal rate of return and Marginal Efficiency of Investment (MEI). There are two determinants of investment efficiency. First, the company feels the need to increase business capital to finance investment opportunities or projects. Second, suppose a company decides on an investment that is trusted to raise capital. In that case, it is not certain that the investment chosen is following the needs, meaning that it requires the proper investment selection. One example, the company needs to increase investment, but managers can choose investments inefficiently or inappropriately. Information asymmetry affects fundraising and project selection, namely the occurrence of information asymmetry between companies and investors (adverse selection) or agency problems between management and shareholders.

If investment increases, economic growth will increase, whereas if investment decreases, economic growth will also decrease. The high level of foreign investment compared to domestic investment has little impact on economic growth due to weak policies in determining the profit-sharing system. Meanwhile, high economic growth will affect increasing the value of exports, imports, and investment; meanwhile, declining economic growth will decrease 
exports, imports, and investment. When an export, import, and investment shock occur, it will affect the agricultural sector's economic growth. Likewise, when there is a shock/shock to economic growth, it will affect exports, imports, and investment. Based on this description, the hypotheses in this study are (1) it is assumed that exports, imports, and investment have an effect on economic growth in the Indonesian agricultural sector; and (2) it is assumed that there is an effect of shock or shock on the export, import and investment variables on economic growth in the agricultural sector.

Exchange rate volatility reflects fluctuations in the exchange rate of a country's currency against other countries' currencies (Sugiharti, Esquivias, \& Setyorani, 2020). The greater the exchange rate volatility, the more volatile and riskier it will be, which will hinder foreign markets' intervention. Exchange rate instability had become a significant concern, especially in economic integration. Trade integration is seen as no longer sufficient to stem the flow of economic globalization. Apart from trade integration, the various currencies used by each country also cause exchange rate volatility. This exchange rate affects the volatility of international trade activities. In this study, the investment can be affected by currency rate volatility, especially for companies dealing with international trade, such as manufacturing industries from other countries.

Measuring the Rupiah's volatility against the US Dollar is very important in making business decisions, especially in the management of translation exposure or exposure to accounting and operations or economic management. The Rupiah's volatility against the US Dollar is also fundamental in planning foreign transactions, preparing company budgets, budget revenues, and expenditures. This study is in the manufacturing industry from other countries, which is high. Measurement of volatility or changes in the fluctuation of the Rupiah exchange rate against the US Dollar is based on the theory of purchasing power, interest rate parity, and the monetary approach to GARCH. According to Sugiharti et al. (2020), the research results that found positive, negative, or no effect of exchange rate volatility on international trade volume are based on various underlying assumptions and only apply in some instances.

Foreign currency exchange rates are significant to economic growth because they affect domestic and foreign goods and services (Bird \& Choi, 2020). The interaction between supply and demand on the foreign exchange market is shown in terms of exchange rates. Such demand and supply conditions are determined by whether the country's essential balance of payments is a surplus or deficit (Civcir et al., 2021). The foreign exchange rate and inflation rate in Indonesia have been marked by volatility, which creates uncertainty in the investment market over the past two decades. Exchange rate volatility means exchange rate movements that result from currency fluctuations.

Regarding previous research that misalignment of growth and actual exchange rates using panel data analysis has grown substantially in the past, and evidence shows that the more depreciated is the country's actual exchange, the faster its long-term growth is. This study shows that significant exchange rates impact developing and developing countries where institutional fragility and a lack of macroeconomic stability are standard features over the last few decades (Haroon \& Jehan, 2020).

A literature review on the impact of exchange rate volatility on economic growth has yielded mixed results. The effect differs from developed to developing countries. Several studies have found significant adverse effects on development. Other studies have found that exchange rate volatility has a positive impact on growth. 
Gaies, Goutte, and Guesmi (2020) analyze exchange rate volatility and growth relationships in Developing Europe and East Asia. To identify the effect of exchange rate volatility on growth, they established an unbalanced cross-country panel model for developing European countries and East Asian countries. The estimation results for Emerging Europe concerning exchange rate volatility against the euro provide evidence that supports the negative correlation between exchange rate volatility and growth. The entire sample's specifications with all control variables indicate that exchange rate volatility against the euro has a clear negative impact on development.

Demir (2013) uses a firm-level dataset to analyze the effects of exchange rate volatility on domestic versus foreign growth performance and publicly traded versus non-trading private manufacturing firms in Turkey. The empirical results using dynamic panel data estimation techniques show that exchange rate volatility has a significant reduction in manufacturing companies' growth effect. However, having access to foreign and domestic equity markets reduces this adverse effect to a substantial degree. Yildiz, Ide, and Malik (2016) used the Engle-Granger cointegration approach to explore Turkey's economic growth and exchange rate volatility relationships, using quarterly data for the 1998-2014 period. The results provide evidence of both a short and long-term relationship between economic growth and economic growth on real effective exchange rates.

On the other hand, several studies have found a positive relationship between exchange rate volatility and growth. Kasman and Kasman (2005) investigated the impact of actual exchange rate volatility on Turkish exports to its most important trading partners using quarterly data from 1982 to 2001. The results show that exchange rate volatility has a significant positive effect on export volume in the long run. These results may suggest that companies operating in small economies, such as Turkey, have few options for dealing with increased exchange rate risk.

On the other hand, Sabina, Manyo, and Ugochukwu (2017) found a negative relationship between exchange rate volatility and Nigeria's economic growth. They use the Generalized Method of Moments (GMM) to estimate the impact of Nigeria's volatility and economic development. The results show that volatility and FDI have a negative and significant impact on Nigerian economic growth. Government Expenditures and External Reserves have a positive and significant effect on Nigeria's economic growth for the period studied. The study recommends that the government and monetary authorities design policies that will stabilize the persistence of the volatility of the naira exchange rate. Odili (2015) analyzes the impact of actual exchange rate volatility and economic growth on exports and imports in Nigeria using a vector error correction model and using time series data from 1971 to 2012. In the short and long run, this study finds that Nigerian trade flows are mainly influenced by exchange rate volatility, real exchange rate, real foreign income, actual gross domestic product, terms of trade, and changes in exchange rate policy. The findings further reveal that exchange rate volatility suppresses trade flows in the long run.

Ahiabo and Amoah (2019) used Fully Modified Ordinary Least Squares (FMOLS) and annual time series data from 1980-2015 to examine the effect of real effective exchange rate volatility on economic growth in Ghana. The regression results show that the actual effective exchange rate volatility has a negative and statistically significant effect on economic growth in Ghana. Besides, they estimate models with traditional control variables and new measures of financial market vulnerability and still have consistent results. Hussain and Farooq (2009) investigated the relationship between economic growth and exchange rate volatility in 
Pakistan using the ARDL model. The cointegration relationship between growth, exchange rate volatility, reserve money, and manufacturing is detected in the long run, except for exports and imports. The conclusion shows that the domestic economy's performance is susceptible to exchange rate volatility in the long run.

Umaru, Aguda, and Davies (2018) examined the effects of exchange rate volatility on the economic growth of English-speaking countries of West Africa. The results obtained indicate that the independent variable (real exchange rate) is statistically significant and negatively related to the dependent variable (GDP) in West Africa's English-speaking countries, excluding time-invariant variables. Musyoki, Pokhariyal, and Pundo (2012) used Generalized Method Moments (GMM) to assess the impact of real exchange rate volatility on economic growth from January 1993 to December 2009 in Kenya. The study found that the RER fluctuated considerably over the entire study period. Kenya's RER generally shows a trend of appreciation and volatility, implying that its international competitiveness deteriorated during the study period. The volatility of the RER reflects the negative impact on the economic growth of Kenya. Bleaney and Greenaway (2001) panel of annual data from 14 sub-Saharan African countries from 1980 to 1995. Sub-Saharan Africa was chosen as a lowincome region that was heavily dependent on exports of significant products. They find that real exchange rate volatility has a significant negative impact on investment and that volatility in trade harms growth.

\section{DATA AND METHOD}

This study's population is in ASEAN member countries that have been published by the World Bank (https://www.worldbank.org/) and continue to exist during the period 1998 to 2019. The sample selection in this study used the purposive sampling method to obtain a representative sample according to the specified criteria. The criteria used to select the sample are as follows:

a. ASEAN countries that have data and are registered with the World Bank from 1998 to 2019 .

b. The country provides complete annual data for the 1998 - 2019 observation year.

c. The country has complete data on Exchange Rate Volatility, Investment, Export, Import, company size, and bank loan interest rates during 1998 - 2019.

The analysis model used is an econometric model. The analysis method used in the model is the path analysis. According to Ozata (2020), as for the model in this study, it can be written as follows:

$$
\ln \text { GDP }=\alpha+\beta_{1} \ln \text { Exp-inv }+\beta_{2} \ln \text { Imp-inv }+\beta_{3} \text { Volex }+\varepsilon_{t}
$$

GDP is Real Gross Domestic Product/economic growth

Exp-inv is the export investment of goods and services

Imp-inv is an import investment of goods and services

Volex is the volatility exchange rate and calculated from the real effective exchange rate. 


\section{RESULT AND DISCUSSION}

Descriptive statistics:

Table no. 1 - Descriptive statistics

\begin{tabular}{|c|c|c|c|c|}
\hline \multicolumn{5}{|c|}{ Indonesia } \\
\hline & $G D P$ & Export & Import & Exchange \\
\hline Mean & $552,405,339,128.96$ & $139,332,428,557.26$ & $130,247,735,823.65$ & $10,255.33$ \\
\hline Min & $95,445,547,872.72$ & $49,720,260,589.81$ & $38,402,067,922.34$ & $7,855.15$ \\
\hline $\operatorname{Max}$ & $1,042,240,309,412.58$ & $235,095,130,017.57$ & $229,602,658,604.78$ & $14,236.94$ \\
\hline Stdv & $342,731,661,238.77$ & $65,987,962,842.09$ & $71,404,876,687.12$ & $1,862.95$ \\
\hline Var & 62.04 & 47.36 & 54.82 & 18.17 \\
\hline \multicolumn{5}{|c|}{ Cambodia } \\
\hline Mean & $10,781,563,641.37$ & $6,399,993,353.15$ & $6,968,424,441.34$ & $4,010.75$ \\
\hline Min & $3,120,425,502.58$ & $974,763,067.89$ & $1,384,886,252.61$ & $3,744.42$ \\
\hline Max & $24,571,753,583.49$ & $15,135,150,382.15$ & $15,554,628,992.25$ & $4,184.92$ \\
\hline Stdv & $6,644,317,873.29$ & $4,216,238,471.90$ & $4,325,180,641.34$ & 109.47 \\
\hline Var & 61.63 & 65.88 & 62.07 & 2.73 \\
\hline \multicolumn{5}{|c|}{ Thailand } \\
\hline Mean & $281,348,231,700.00$ & $187,771,480,780.29$ & $168,882,764,552.77$ & 36.23 \\
\hline Min & $129,981,229,222.81$ & $90,273,508,632.27$ & $82,036,097,908.97$ & 4.38 \\
\hline Max & $506,514,103,905.27$ & $328,570,049,086.67$ & $283,801,678,726.84$ & 44.43 \\
\hline Stdv & $6,644,317,873.29$ & $4,216,238,471.90$ & $4,325,180,641.34$ & 109.47 \\
\hline Var & 46.2 & 48.08 & 48.58 & 12.09 \\
\hline \multicolumn{5}{|c|}{ Vietnam } \\
\hline Mean & $108,504,212,513.73$ & $89,277,448,150.10$ & $90,898,609,279.69$ & $17,838.17$ \\
\hline Min & $27,209,602,050.05$ & $12,203,044,875.11$ & $14,190,608,828.55$ & $13,268.00$ \\
\hline Max & $245,213,686,369.16$ & $259,514,070,626.34$ & $251,282,383,677.59$ & $22,602.05$ \\
\hline Stdv & $72,724,740,756.75$ & $76,601,856,252.08$ & $72,872,887,511.18$ & $3,169.92$ \\
\hline Var & 67.02 & 85.8 & 80.17 & 17.77 \\
\hline
\end{tabular}

The results of Table no. 1 show that the GDP variable in Indonesia is the variable with the most considerable degree of variation compared to other variables. This matter can be seen from the highest coefficient of variation. The variable with a constant level of variation is the Indonesian currency exchange rate during 1998-2019. The same is true of Cambodia.

Furthermore, the whole country's results show that during the period 1998 to 2019, the level of exports and imports in ASEAN countries, especially Indonesia, Cambodia, Thailand, and Vietnam, tended to fluctuate highly. Meanwhile, the exchange rate variable in the four countries tends to experience constant changes.

The Effect of Volatility Exchange Rate on Export Investment in the ASEAN Region:

Table no. 2 - Volatility and Export Investment

\begin{tabular}{llcc}
\hline \multicolumn{1}{c}{ Variable } & \multicolumn{1}{c}{ Coefficient } & Standard error & p-value \\
\hline Constant & 10.800 & 0.046 & 0.000 \\
Volatility & -24.874 & 7.572 & $0.001^{*}$ \\
\hline $\mathrm{R}^{2}$ & \multicolumn{3}{c}{0.807} \\
Adjusted $\mathrm{R}^{2}$ & \multicolumn{3}{c}{0.798} \\
Prob F-stat & \multicolumn{3}{c}{0.000} \\
\hline \multicolumn{4}{c}{ Source: the authors' analysis results }
\end{tabular}


The variable of exchange rate volatility in this study is calculated using a moving average standard deviation. In calculating currency volatility, it is calculated based on the difference to the average value of the currency or the variation during the 1998-2019 period.

The test results show that the volatility variable is significant at alpha one percent $(1 \%)$ with a negative coefficient sign, namely 24.874 . The negative coefficient sign shows that the increase in exchange rate volatility decreases the export investment value of countries in the ASEAN region. This result supported the previous research by Caglayan and Torres (2011) and Zivkov, Kuzman, and Andrejević-Panić (2020), which found that volatility has a negative effect on investment for export-oriented companies.

Test result indicates that although it has a significant effect, volatility has a significant impact on export investment. In contrast to the findings of Avdjiev, Bruno, Koch, and Shin (2019), which shows that in various countries, the exchange rate tends to have a weak influence on the level of investment.

The negative coefficient value indicates that the majority of exporters in ASEAN countries are risk-averse. This result means that with a high level of volatility, the trend in exports will decline. This finding implies that investors in the export sector do not want to take significant risks on exchange rate movements. Moreover, with considerable risk, the revenue received from export investment activities will also tend to fluctuate significantly. Therefore, with high volatility, export investors tend to maintain their income by reducing exports abroad.

The Effect of Volatility Exchange Rate on Import Investment in the ASEAN Region:

Table no. 3 - Volatility and Import Investment

\begin{tabular}{llcc}
\hline \multicolumn{1}{c}{ Variable } & Coefficient & Standard error & p-value \\
\hline Constant & 10.795 & 0.046 & 0.000 \\
Volatility & -25.196 & 7.451 & $0.001^{*}$ \\
\hline $\mathrm{R}^{2}$ & \multicolumn{3}{c}{0.791} \\
Adjusted $\mathrm{R}^{2}$ & & 0.781 \\
Probability F-statistic & 0.000 \\
\hline \multicolumn{4}{c}{ Source: the authors' analysis results }
\end{tabular}

The negative coefficient sign shows that the increase in exchange rate volatility decreases import investment value in countries in the ASEAN region. Besides, it can also be seen that the effect of volatility has a more significant impact on import investment than on export investment in ASEAN countries.

The research finding is opposite to Thuy and Thuy (2019) result that depreciation will have a positive effect on total investment when exchange rate volatility is low. However, this stimulative effect becomes much smaller as the volatility increases. A negative coefficient value also indicates that the majority of importers are risk-averse, as well as happened to the exports. This finding means that with high volatility, the trend of imports will also decrease. It implies that investors in the import sector do not want to take significant risks on exchange rate movements. This due to if the exchange rate volatility moves up, the importer must pay more for the imported goods. This result means that the goods value's increases when the exchange rate depreciates against the dollar in the ASEAN Region.

The Effect of Volatility Exchange Rate on Economic Growth in the ASEAN Region: 
Table no. 4 - Volatility and Economic Growth

\begin{tabular}{lccl}
\hline \multicolumn{1}{c}{ Variable } & Coefficient & Standard error & p-value \\
\hline Constant & 11.068 & 0.043 & 0.000 \\
Volatility & -21.317 & 7.075 & $0.003^{*}$ \\
\hline $\mathrm{R}^{2}$ & & 0.848 \\
Adjusted $\mathrm{R}^{2}$ & & 0.840 \\
Probability F-statistics & \multicolumn{2}{c}{0.000} \\
\hline \multicolumn{3}{c}{ Source: The authors' analysis results }
\end{tabular}

The coefficient sign is negative, which indicates that the greater the exchange rate volatility, the lower the economic growth of countries in the ASEAN region. This result suggests that volatility is tremendous on economic growth the ASEAN countries. Furthermore, this result is different from research by $\mathrm{Chen}, \mathrm{Du}$, and $\mathrm{Hu}$ (2020), which found that exchange rate volatility is not significant to economic growth. A negative sign indicates that exchange rate volatility is transmitted through exports and imports to economic growth.

The Effect of Export/Import Investment on Economic Growth in the ASEAN Region:

Table no. 5 - Export Investment and Economic Growth

\begin{tabular}{lccc}
\hline \multicolumn{1}{c}{ Variable } & Coefficient & Standard error & p-value \\
\hline Constant & 1.402 & 0.313 & 0.000 \\
Export & 0.819 & 0.027 & $0.000^{*}$ \\
\hline $\mathrm{R}^{2}$ & \multicolumn{3}{c}{0.918} \\
Adjusted $\mathrm{R}^{2}$ & & 0.907 \\
Probability F-statistic & \multicolumn{3}{c}{0.000} \\
\hline \multicolumn{4}{c}{ Source: The authors' analysis results }
\end{tabular}

The coefficient sign of the variable results is positive, which is following the hypothesis. This result means that the greater the export value, the more economic growth of countries in the ASEAN region will be observed. This finding supported with the research of Kasman and Kasman (2005), Swift (2006) and Yu, Zhao, Niu, and Lu (2020).

Regarding these results, Lee (2017) explains that exports investment have an essential role as a key driver the national economy because they generate foreign exchange. The foreign exchange generated can be reused to finance imports and the development of domestic economic sectors. Besides, exports open up the opportunities for broader new markets to maximize domestic production. Market expansion has a positive effect on the country because it absorbs more workers to increase production and stimulates economic growth. Descriptive analysis shows that Indonesia, Thailand, Vietnam, and Cambodia's average export value is more than 400 million dollars. With a substantial export value, it is certainly able to increase the economic growth of these countries.

Table no. 6 - Import Investment and Economic Growth

\begin{tabular}{lccc}
\hline \multicolumn{1}{c}{ Variable } & Coefficient & Standard error & p-value \\
\hline Constant & 1.177 & 0.271 & 0.000 \\
Import & 0.921 & 0.022 & $0.000^{*}$ \\
\hline $\mathrm{R}^{2}$ & & & 0.961 \\
Adjusted $\mathrm{R}^{2}$ & & & 0.935 \\
Probability F-statistic & & 0.000 & \\
\hline
\end{tabular}

Source: The authors' analysis results 
The estimation results show that the import investment has significant effect and positive sign. It is indicating that more excellent import investment is followed by sufficient economic growth in ASEAN countries. This finding is different from Dao et al. (2017) which showed an insignificant effect due to the increase in imports of goods entering the country, which was not followed by the rise in other economic activities. This result shows that the majority of imported goods are used as capital in creating other productive or economic activities. Increasing productive activities and business fields will ultimately increase the country's economic growth.

Indirect Effect Test of Volatility Exchange Rate on Economic Growth

Sobel test is used to analyze the magnitude of the indirect effect of volatility exchange rates changes through exports and imports investment on ASEAN economic growth. Table below shows the result test:

Table no. 7 - Sobel Test Results

\begin{tabular}{cccc}
\hline Variable & Z-test & Z-table & Conclusion \\
\hline Volatility $\longrightarrow$ export $\longrightarrow$ GDP & 7.801 & 1.965 & Significant \\
Volatility $\longrightarrow$ import $\longrightarrow$ GDP & 7.804 & 1.965 & Significant \\
\hline
\end{tabular}

The Sobel test shows a significant value. This result suggests that exports or imports investment mediated exchange rate volatility on economic growth in the ASEAN region significantly (Asad, Tabash, Sheikh, Al-Muhanadi, \& Ahmad, 2020). This significant impact shows that the ASEAN region's economic growth is influenced by exchange rate volatility, which is transmitted through export and import investment. Thus, shocks to exchange rate volatility can reduce the economic growth of countries in the ASEAN region.

\section{CONCLUSION}

Based on the results of research on the effect of exchange rate volatility on investment in ASEAN Member countries (Indonesia, Thailand, Vietnam, and Cambodia), all determinants impact the dependent variables. The resulting finding also shows that export/import mediates the exchange rate volatility and economic growth. This finding implies that the transmission of export/import investment will affect the relationship between exchange rate volatility and economic growth.

These results findings provide the following suggestions: regarding the investor's perspective, the outcome can provide the information needed in making investment decisions, particularly for developing the economy of a foreign affiliate. The result can provide an overview of the importance of investment analysis in the decision to determine exports and imports and the dominant factors that affect the increase in value so that the issuer can be sensitive to fluctuations in currency exchange rates in ASEAN countries. Future research can be used for the many factors that can affect the level of investment outside the factors that have been analyzed.

\section{Acknowledgements}

For helpful supports, we thank to our Dean of Faculty of Economics Universitas Negeri Jakarta Indonesia. 


\section{ORCID}

Gatot Nazir Ahmad (iD https://orcid.org/0000-0002-2274-9499

Haryo Kuncoro (D) https://orcid.org/0000-0002-4512-1389

\section{References}

Ahiabo, G., \& Amoah, A. (2019). Examining the effect of real effective exchange rate volatility on economic growth: Evidence from Ghana. Journal of Economics and Economic Education Research, 20(1), 1-14.

Ahiakpor, J. C. W. (2020). Disputing the correct interpretation of say's law: A comment on Roy Grieve's and Steven Kates's arguments. History of Economics Review, 77(1), 37-51. http://dx.doi.org/10.1080/10370196.2020.1784649

Alaali, F. (2020). The effect of oil and stock price volatility on firm level investment: The case of UK firms. Energy Economics, 87(March), 104731. http://dx.doi.org/10.1016/j.eneco.2020.104731

Andren, N., \& Jankensgard, H. (2020). Disappearing investment-cash flow sensitivities: Earnings have not become a worse proxy for cash flow. Journal of Business Finance \& Accounting, 47(5-6), 760-785. http://dx.doi.org/10.1111/jbfa.12427

Andries, P., \& Hunermund, P. (2020). Firm-level effects of staged investments in innovation: The moderating role of resource availability. Research Policy, 49(7), 103994. http://dx.doi.org/10.1016/j.respol.2020.103994

Asad, M., Tabash, M. I., Sheikh, U. A., Al-Muhanadi, M. M., \& Ahmad, Z. (2020). Gold-oil-exchange rate volatility, Bombay stock exchange and global financial contagion 2008: Application of NARDL model with dynamic multipliers for evidences beyond symmetry. Cogent Business \& Management, 7(1), 1849889. http://dx.doi.org/10.1080/23311975.2020.1849889

Avdjiev, S., Bruno, V., Koch, C., \& Shin, H. S. (2019). The dollar exchange rate as a global risk factor: Evidence from investment. IMF Economic Review, 67, 151-173. http://dx.doi.org/10.1057/s41308-019-00074-4

Beckmann, J., Czudaj, R. L., \& Arora, V. (2020). The relationship between oil prices and exchange rates: Revisiting theory and evidence. Energy Economics, 88, 104772. http://dx.doi.org/10.1016/j.eneco.2020.104772

Bhattacharya, A., Good, V., \& Sardashti, H. (2020). Beyond warm glow: The risk-mitigating effect of corporate social responsibility (CSR). Journal of Business Ethics(January). http://dx.doi.org/10.1007/s10551-020-04445-0

Bird, G., \& Choi, Y. (2020). The effects of remittances, foreign direct investment, and foreign aid on economic growth: An empirical analysis. Review of Development Economics, 24(1), 1-30. http://dx.doi.org/10.1111/rode.12630

Bleaney, M., \& Greenaway, D. (2001). The impact of terms of trade and real exchange rate volatility on investment and growth in sub-Saharan Africa. Journal of Development Economics, 65(2), 491500. http://dx.doi.org/10.1016/S0304-3878(01)00147-X

Caglayan, M., \& Torres, R. I. M. (2011). The effect of the exchange rates on investment in Mexican manufacturing industry. Open Economies Review, 22(4), 669-683. http://dx.doi.org/10.1007/s11079-010-9166-0

Chen, L., Du, Z., \& Hu, Z. (2020). Impact of economic policy uncertainty on exchange rate volatility of China. Finance Research Letters, 32, 101266. http://dx.doi.org/10.1016/j.frl.2019.08.014

Civcir, I., Panshak, Y., \& Ozdeser, H. (2021). A multi-sectoral balance of payments constrained growth approach with intermediate imports: The case of Nigeria. Structural Change and Economic Dynamics, 6, 240-250. http://dx.doi.org/10.1016/j.strueco.2020.12.002

Dao, M. C., Minoiu, C., \& Ostry, J. (2017). Corporate investment and the real exchange rate. IMF Working Papers, 17. http://dx.doi.org/10.5089/9781484313749.001 
Demir, F. (2013). Growth under exchange rate volatility: Does access to foreign or domestic equity markets matter? Journal of Development Economics, 100(1), 74-88. http://dx.doi.org/10.1016/j.jdeveco.2012.08.001

Edo, S., Osadolor, N. E., \& Dading, I. F. (2020). Growing external debt and declining export: The concurrent impediments in economic growth of Sub-Saharan African countries. Inter Economics, 161, 73-187. http://dx.doi.org/10.1016/j.inteco.2019.11.013

Gaies, B., Goutte, S., \& Guesmi, K. (2020). Does financial globalization still spur growth in emerging and developing countries? Considering exchange rates. Research in International Business and Finance, 52(April), 101113. http://dx.doi.org/10.1016/j.ribaf.2019.101113

Haroon, R., \& Jehan, Z. (2020). Measuring the impact of violence on macroeconomic instability: Evidence from developing countries. Portuguese Economic Journal(November) http://dx.doi.org/10.1007/s10258-020-00188-y

Hotei, M. (2012). The effects of the exchange rate on Japanese firm's investment: An analysis with firmlevel data. Public Policy Review, 8(5), 663-682.

Hussain, Z. J., \& Farooq, M. (2009). Economic growth and exchange rate volatility in the case of Pakistan. Pakistan Journal of Life and Social Sciences, 7(2), 112-118.

Ishikawa, K. (2021). The ASEAN economic community and ASEAN economic integration. Journal of $\begin{array}{llll}\text { Contemporary } \quad \text { East } & \text { Asia }\end{array}$ http://dx.doi.org/10.1080/24761028.2021.1891702

Kasman, A., \& Kasman, S. (2005). Exchange rate uncertainty in Turkey and its impact on export volume. METU Studies in Development, 32, 41-58.

Lee, M. (2017). The impact of exchange rate on firm performance: Evidence from Korean firms. Emerging Markets Finance \& Trade, 53(11), 2440-2449. http://dx.doi.org/10.1080/1540496X.2017.1322504

Michail, N. A. (2021). The impact of conflict on the exchange rate of developing economies. Review of Development Economics, 00, 1-15. http://dx.doi.org/10.1111/rode.12749

Mlambo, C. (2020). Exchange rate and manufacturing sector performance in SACU states. Cogent Business \& Management, 7(1), 1787735. http://dx.doi.org/10.1080/23311975.2020.1787735

Musyoki, D. P., Pokhariyal, G., \& Pundo, M. (2012). The impact of real exchange rate volatility on economic growth: Kenyan evidence. Business and Economic Horizons, 7(8), 59-75. http://dx.doi.org/10.15208/beh.2012.5

Nucci, F., \& Pozzolo, A. F. (2001). Investment and the exchange rate: An analysis with firm-level panel data. European Economic Review, 45(2), 259-283. http://dx.doi.org/10.1016/S00142921(00)00050-7

Odili, O. (2015). Real exchange rate volatility, economic growth and international trade in an emerging market economy: Evidence from Nigeria. International Journal of Academic Research in Business \& Social Sciences, 5(7), 179-201. http://dx.doi.org/10.6007/ijarbss/v5-i7/1730

Oglend, A., \& Straume, H. M. (2020). Futures market hedging efficiency in a new futures exchange: Effects of trade partner diversification. Journal of Futures Markets, 40(4), 617-631. http://dx.doi.org/10.1002/fut.22088

Ozata, E. (2020). The effect of exchange rate volatility on economic growth in Turkey. Pressacademia, 9(1), 42-51. http://dx.doi.org/10.17261/pressacademia.2020.1191

Permani, R. (2021). FTA, Exchange rate pass-through and export price behavior - Lessons from the Australian dairy sector. The Australian Journal of Agricultural and Resource Economics, 65(1), 192-221. http://dx.doi.org/10.1111/1467-8489.12402

Primi, A., \& Toselli, M. (2020). A global perspective on industry 4.0 and development: New gaps or opportunities to leapfrog? Journal of Economic Policy Reform, 23(4), 371-389. http://dx.doi.org/10.1080/17487870.2020.1727322

Rapetti, M. (2020). The real exchange rate and economic growth: A survey. Journal of Globalization and Development, 11(2), 20190024. http://dx.doi.org/10.1515/jgd-2019-0024 
Sabina, N. E., Manyo, T. S., \& Ugochukwu, U. S. (2017). Modeling exchange rate volatility and economic growth in Nigeria. International Journal of Economics. International Journal of $\begin{array}{llll}\text { Economics, } \quad \text { Commerce } \quad \text { and } & \text { 8nagement, }\end{array}$ http://dx.doi.org/10.5901/mjss.2012.v3n3p399

Sugiharti, L., Esquivias, M. A., \& Setyorani, B. (2020). The impact of exchange rate volatility on Indonesia's top exports to the five main export markets. Heliyon, 6(1), e03141. http://dx.doi.org/10.1016/j.heliyon.2019.e03141

Swift, R. (2006). Measuring the effects of exchange rate changes on investment in Australian manufacturing industry. Economic Record, 22(1), 19-25. http://dx.doi.org/10.1111/j.14754932.2006.00329.x

Thuy, V. N. T., \& Thuy, D. T. T. (2019). The impact of exchange rate volatility on exports in Vietnam: A bounds testing approach. Journal of Risk and Financial Management, 12(1), 6. http://dx.doi.org/10.3390/jrfm12010006

Umaru, H., Aguda, N. A., \& Davies, N. O. (2018). The Effects of Exchange Rate Volatility on Economic Growth of West African English-Speaking Countries. International Journal of Academic Research in Accounting. International Journal of Academic Research in Accounting, Finance and Management Sciences, 8(4), 131-143. http://dx.doi.org/10.6007/IJARAFMS/v8-i4/5470

Vaio, A. D., Palladino, R., Hassan, R., \& Escobar, O. (2020). Artificial intelligence and business models in the sustainable development goals perspective: A systematic literature review. Journal of Business Research, 121, 283-314. http://dx.doi.org/10.1016/j.jbusres.2020.08.019

Yildiz, H., Ide, G., \& Malik, S. (2016). The relationship between exchange rate volatility and economic growth: An example of Turkey. International Journal of Arts and Commerce, 5(3), 47-61.

Yu, L., Zhao, D., Niu, H., \& Lu, F. (2020). Does the belt and road initiative expand China's export potential to countries along the belt and road? China Economic Review, 60, 101419. http://dx.doi.org/10.1016/j.chieco.2020.101419

Zivkov, D., Kuzman, B., \& Andrejević-Panić, A. (2020). Nonlinear bidirectional multiscale volatility transmission effect between stocks and exchange rate markets in the selected African countries.
Economic
Research-Ekonomska
Istraživanja
34(1),
$1623-1650$ http://dx.doi.org/10.1080/1331677X.2020.1844585

\section{Copyright}

This article is an open access article distributed under the terms and conditions of the Creative Commons Attribution-NonCommercial-NoDerivatives 4.0 International License. 